ORIGINAL ARTICLE / ARTIGO ORIGINAL

\title{
Discrimination based on sexual orientation against MSM in Brazil: a latent class analysis
}

\section{Discriminação por orientação sexual entre HSH no Brasil: uma análise de classes latentes}

\author{
Laio Magno ${ }^{\prime, \| 1}$ (D), Luís Augusto V. da Silva",III (D), Mark Drew Crosland Guimarães ${ }^{\mathrm{IV}}$ (D), \\ Maria Amélia de Sousa Mascena Veras ${ }^{\mathrm{V}}$ (D), Luiz Fábio Alves de Deus ${ }^{\mathrm{Vl}}$ (D), Andrea Fachel LealVII (D), \\ Daniela Riva Knauth ${ }^{\mathrm{VIII}}$ (D), Ana Maria de Brito ${ }^{\mathrm{X}}$ (D), Gustavo Machado Rocha ${ }^{\mathrm{X}}$ (D), \\ Luana Nepomuceno Gondim Costa Lima ${ }^{\mathrm{XI}}$, Carl Kendall ${ }^{\mathrm{XI}}$ (D), \\ Ana Rita Coimbra Motta-Castro ${ }^{\mathrm{XII}}$ (D), Ligia Regina Franco Sansigolo Kerr ${ }^{\mathrm{XI}}$ (D), \\ Rosa Maria Salani Mota ${ }^{\mathrm{XIV}}$ (D), Edgar Merchan-Hamann ${ }^{\mathrm{XV}}$ (D), Inês Costa Dourado" (D), \\ The Brazilian HIV/MSM Surveillance Group*
}

\begin{abstract}
Introduction: Discrimination based on sexual orientation can influence vulnerability to HIV, increasing exposure to risky sexual behavior among men who have sex with men (MSM). Objectives: To analyze data using latent class analysis (LCA) to identify groups of individuals with specific patterns of discrimination based on sexual orientation (DSO). Methods: Cross-sectional study using respondent-driven sampling in 12 Brazilian cities in 2016. LCA was used to characterize discrimination among MSM based on 13 variables in the survey questionnaire. The proportions of men reporting DSO and other variables of interest were estimated using Gile's Successive Sampling estimator. Results: Most MSM were young, single, had a religion, had a high school or college degree, black or brown skin color, and socioeconomic status classified as average. More than half of the participants reported that they had been discriminated against during the last 12 months due to their sexual orientation $(65 \%)$, more than a third said they had felt afraid of walking in public places during the past 12 months, and about one-fifth of participants reported having been victims of physical or sexual assault due to DSO. DSO was classified into four latent classes: "very high", "high", "moderate" and "low", with estimates of $2.2 \%, 16.4 \%, 35.1 \%$, and $46.19 \%$, respectively. Conclusion: We observed a high proportion of discrimination against MSM in this study. The use of LCA differentiated parsimoniously classes of discrimination.
\end{abstract}

Keywords: MSM. Social discrimination. Sexual orientation. Latent class analysis. Brazil.

*Alexandre Kerr Pontes, Ana Cláudia Camillo, Ana Maria de Brito, Ana Rita Coimbra Motta-Castro, Daniela Riva Knauth, Andréa Fachel Leal, Edgar Merchan-Hermann, Ximena Pamela Diaz, Luana Nepomuceno Gondim Costa Lima, Maria Amélia Veras, Inês Dourado, Lígia Regina Franco Sansigolo Kerr, Lisangela Cristina de Oliveira, Mark Drew Crosland Guimarães, Raimunda Hermelinda Maia Macena, Rosa Salani Mota, Maria do Socorro Cavalcante, Carl Kendall, Cristina Pimenta, and Ana Roberta Pati Pascom.

'Department of Life Sciences, State University of Bahia - Salvador (BA), Brazil.

"Institute of Collective Health, Federal University of Bahia - Salvador (BA), Brazil.

I'Institute of Humanities, Arts \& Sciences Professor Milton Santos, Federal University of Bahia - Salvador (BA), Brazil.

"Faculty of Medicine, Department of Preventive and Social Medicine, Federal University of Minas Gerais - Belo Horizonte (MG), Brazil. vFaculty of Medical Sciences, Santa Casa de São Paulo - São Paulo (SP), Brazil.

v'Graduate Program in Social and Institutional Psychology, Federal University of Rio Grande do Sul - Porto Alegre (RS), Brazil. VIIDepartment of Sociology. Institute of Philosophy and Human Sciences. Federal University of Rio Grande do Sul - Porto Alegre (RS), Brazil

VIIIDepartment of Social Medicine, Faculty of Medicine, Federal University of Rio Grande do Sul - Porto Alegre (RS), Brazil.

|xInstituto Aggeu Magalhães, Oswaldo Cruz Foundation - Recife (PE), Brazil.

xFederal University of São João Del-Rei - Divinópolis (MG), Brazil.

x'Department of Bacteriology and Mycology, Instituto Evandro Chagas - Ananindeua (PA), Brazil.

${ }^{x \|}$ Center for Global Health Equity, Tulane School of Public Health and Tropical Medicine - New Orleans (LA), United States.

xil'Laboratory of Clinical Immunology, Faculty of Pharmaceutical Sciences, Food and Nutrition, Federal University of Mato Grosso do Sul - Campo Grande (MS), Brazil.

xv Department of Community Health, Federal University of Ceará - Fortaleza (CE), Brazil.

xv Department of Collective Health, University of Brasília - Brasília (DF), Brazil.

Corresponding author: Laio Magno. Department of Life Sciences, State University of Bahia, Campus I, Cabula, CEP: 41 150-000, Salvador, BA, Brazil. E-mail: laiomagnoss@gmail.com

Conflict of interests: nothing to declare - Financial support: Ministry of Health, through the Department of Health Surveillance and the Department of Chronic Conditions Diseases and Sexually Transmitted Infections. 
RESUMO: Introdução: A discriminação por orientação sexual (DPOS) pode influenciar a vulnerabilidade ao HIV aumentando a exposição a comportamentos sexuais de risco entre homens que fazem sexo com homens (HSH). Objetivos: Examinar dados utilizando a análise de classes latentes (ACL) para identificar grupos de indivíduos com padrões específicos de DPOS. Métodos: Estudo transversal com entrevistados recrutados pelo processo amostral respondent driven sampling em 12 cidades brasileiras em 2016. A ACL foi usada para caracterizar o DPOS entre HSH com base em 13 variáveis do bloco de discriminação do questionário da pesquisa. As proporções de DPOS e das variáveis de interesse, bem como seus intervalos de confiança (95\%) foram ponderados usando o estimador de Gile. Resultados: A maioria era de jovens, solteiros, com alguma religião, escolaridade média ou superior, cor da pele preta ou parda e com nível socioeconômico médio. Mais da metade referiu ter sido discriminado nos últimos 12 meses por sua orientação sexual (65\%), mais de um terço referiu ter tido medo de andar em lugares públicos nos últimos 12 meses e em torno de um quinto dos participantes reportaram ter sofrido agressão física ou sexual na vida. A DPOS foi classificada em 4 classes latentes, "muito alta", "alta", "média" e "baixa", com estimativas de 2,2\%, 16,4\%, 35,1\% e 46,19\%, respectivamente. Conclusão: Observou-se alta proporção de discriminação entre os HSH participantes deste estudo. A utilização da ACL discriminou de maneira parcimoniosa as classes de DPOS.

Palavras-chave: HSH. Discriminação social. Orientação sexual. Análise de classes latentes. Brasil.

\section{INTRODUCTION}

Men who have sex with men (MSM) are a population group that is often the target of stigma, discrimination, and various types of violence because their sexual affections, desires, and practices are directed towards someone who has the same gender as themselves. Hostility against nonheterosexual people persists because there is a heteronormative system that regards homosexuality as abnormal, immoral or even as a deviation of character, leading this population to experience many disadvantages ${ }^{1}$.

Discrimination has been defined as a set of negative attitudes and behaviors against people or population groups. It is based on characteristics or traits socially perceived as "derogatory" and can lead to unequal treatment, loss of opportunities, exclusions, and deprivation ${ }^{2,3}$. Authors such as Krieger ${ }^{4}$ refer to discrimination as any set of institutionalized social expressions and relationships of domination and oppression whose aim is to uphold the power and the system of privileges.

Parker and Aggleton ${ }^{5}$ emphasize that stigma and discrimination must be understood beyond the behavioral or even cultural spheres, and should rather be understood as social processes closely related to the dissemination of social exclusion and inequalities. Discrimination based on sexual orientation (DSO) may be manifested in the individual, interpersonal, institutional, and structural dimensions, and constitutes an important social determinant for the health of the lesbian, gay, bisexual, and transgender (LGBT) population ${ }^{1}$.

In the last decades, new theoretical frameworks have been elaborated to elucidate the consequences of discriminatory practices experienced daily by LGBTs. Among such 
contributions, the concept of minority stress, proposed by Meyer ${ }^{6}$, is particularly interesting. Meyer ${ }^{6}$ states that sexual minorities experience unique forms of stress and that the continuous and constant character of this stress directly affects their physical and mental health.

Another relevant concept to understand the discrimination against the homosexual population is that proposed by Sue $\mathrm{S}^{7}$, denominated as "microaggression". According to this author, the stigmatizing character of homosexuality leads to daily and repeated exposition to small insults, humiliations, and curses perpetrated generally by "well-intentioned" people who are close to the person insulted. As such smaller comments are not explicitly aggressive or violent, those who are insulted do not perceive those as having been intentional; however, as these microaggressions are continuous, albeit not always perceived as such by those who receive such messages, they tend to humiliate and threaten the identity of those who are insulted, leading to micro social inequities.

Studies point to the association between discrimination and practices that may put health at risk, such as the use of psychoactive substances ${ }^{8,9}$, abusive use of alcohol ${ }^{10}$, symptoms of psychological stress ${ }^{11}$, depressive symptoms $s^{12,13}$, as well as unprotected anal sex ${ }^{14}$ and history of sexually transmitted infections (STIs) ${ }^{15}$. DSO plays an important role in the vulnerability of MSM to HIV/AIDS in several countries ${ }^{16}$.

Krieger $^{4,17}$ gives an important overview of methodological issues regarding public health research of discrimination and emphasizes that measuring discrimination is complex. Among the strategies for measuring discrimination, the author highlights direct and indirect methods. The indirect method is developed by observing discriminatory practices and is useful in situations in which the discriminatory act is not consciously realized as violence. The direct measurement, in turn, is performed by collecting self-reports of discrimination, and the author emphasizes that special attention should be given to the standardization of instruments and measurements regarding the collection of data on the period of exposure, the context in which the episode occurred, the intensity and frequency of discrimination, and those who were discriminated against. Studies usually use the direct measurement method for DSO, by administering questionnaires created for this purpose $\mathrm{e}^{18-20}$, based on formative research ${ }^{13}$, or even adapted from other discrimination scales, such as racial discrimination ${ }^{21}$ and HIV-related stigma ${ }^{9}$

Data on DSO may also be analyzed in different ways. Most of the observational studies addressing this issue analyze data on DSO using a single variable, usually some form of the question "Have you ever felt discriminated against because of your sexual orientation?". However, some recent studies have used other analytical strategies, such as: (1) the use of several items of a questionnaire to create indicators and of the respective Cronbach's alpha coefficient ${ }^{11,13,21}$; (2) the sum of the answers of discrimination variables with no statistical test associated ${ }^{20}$; and (3) the exploratory factor analysis of a set of variables regarding discrimination ${ }^{15,18}$.

Traditional forms of analysis may not fully capture the DSO circumstances, especially when dichotomous variables are employed. Latent class analysis (LCA) is thus a useful statistical method for identifying underlying groups of individuals who have similar profiles, which may be used to classify individuals into latent (unobserved) classes when there is a set of highly-related categorical variables. This method differs from multivariate analyses that examine the independent association of each variable with the outcome variable, keeping 
other variables constant. LCA seeks to identify groups of individuals who share similar response profiles regarding classification variablesa and provides information on how several variables interact with each other to predict the outcome variable ${ }^{22}$.

Faced with the complexity of DSO and the scarcity of data on the subject, this study aims to use the LCA to identify and describe groups of MSM with specific patterns of DSO.

\section{METHODS}

\section{SETTINGS, DESIGN AND STUDY POPULATION}

This is a behavioral and biological survey entitled "Estudo de abrangência nacional de comportamentos, atitudes, práticas e prevalência de HIV, sífilis e hepatites B e C entre HSH" (Nationwide study of behaviors, attitudes, practices, and prevalence of HIV, syphilis and hepatitis B and C among MSM), conducted in 2016 in 12 Brazilian capital cities: Manaus (AM) and Belém (PA), in the Northern region; Fortaleza (CE), Recife (PE), and Salvador (BA), in the Northeast region; Brasília (DF) and Campo Grande (MS), in the Center-West region; Belo Horizonte (MG), Rio de Janeiro (RJ), and São Paulo (SP), in the Southeast region; and Curitiba (PR) and Porto Alegre (RS), in the Southern region ${ }^{23,24}$

The study sample consisted of men who reported at least one sexual relationship with another man in the 12 months previous to the survey. Other inclusion criteria were to be 18 years of age; not to identify himself as a transvestite or transsexual woman; to live, study or work in the cities selected for the study; and to agree to invite other MSM to participate in the study. Respondent-driven sampling (RDS) method was used for the recruitment of participants ${ }^{25,26}$.

\section{DATA COLLECTION}

Data were collected through structured interviews and/ or self-applied questionnaires using tablets. All participants received HIV counseling, educational materials, and condoms. The study was approved by the Research Ethics Committee of the Federal University of Ceará.

The research project was approved by Federal University of Ceará (no. CAAE43133915.9.0000.5054 / decision number 1.024.053).

\section{INDICATORS AND DATA ANALYSIS}

We analyzed the following variables in this study: (1) sociodemographic variables: age ( $<25$ years old or $\geq 25$ years old), self-reported skin color (white; black; brown; indigenous / native: or Asian descent), schooling (college or high school degree; or incomplete high school 
or complete elementary/middle school), having a religion (yes or no), marital status (single; separated or widowed; or married, living together or in a common-law marriage); (2) economic variables, allowing for the construction of three socioeconomic strata (A-B: higher; C: middle; and D-E: lower) according to the "Critério Brasil" model (Brazil Criteria of Economic Classification); history of violence: (3) sexual (yes or no) and physical (yes or no); (4) fear of walking in public places (yes or no); and (5) discrimination: self-report of discrimination based on sexual orientation in life (yes or no). For the LCA, 13 questions related to the self-report of DSO in the last 12 months were used and grouped into four dimensions (DSO in the work sphere, in the educational setting, in the private domain and in the public sphere - available in Table 1), according to the theoretical review of the construct. All 13 questions could be answered with "often", "sometimes", "a few times", or "only once", which in turn were grouped as "yes = 1"; and "never", which was considered "no $=0$ ".

Chart 1. Description of the variables constituting the dimensions of DSO in the last 12 months.

\section{Variable}

Discrimination in the work sphere

Have you ever been not selected for a job or fired from a job because of your sexual orientation?

Discrimination in the educational setting

Have you ever been mistreated or marginalized by teachers in school/college because of your sexual orientation?

Have you ever been mistreated or marginalized by classmates at school/college because of your sexual orientation?

\section{Discrimination in the private domain}

Have you ever been excluded or marginalized in a religious environment because of your sexual orientation?

Have you ever been excluded or marginalized in groups of friends because of your sexual orientation?

Have you ever been excluded or marginalized in groups of neighbors because of your sexual orientation?

Have you ever been excluded or marginalized in your family environment because of your sexual orientation?

\section{Discrimination in the public sphere}

Have you ever been blackmailed or extorted money because of your sexual orientation?

Have you ever been poorly cared for in health services or by health professionals because of your sexual orientation,?

Have you ever been prevented from donating blood because of your sexual orientation?

Have you ever been poorly served or mistreated in public services because of your sexual orientation?

Have you ever been mistreated by police officers or poorly served in police stations because of your sexual orientation?

Have you ever been poorly served or prevented from entering a commercial establishment or social venue because of your sexual orientation? 
LCA was performed using Mplus 5.21 ${ }^{27}$ software. We used the parameters of the LCA analysis - class prevalences and item response probabilities - to describe the latent classes in the final model selected. Criteria for the selection of the best model was the Bayesian information criterion (BIC) and the Akaike information criterion (AIC) because these criteria allow for the comparison between models considering the balance between adjustment and parsimony, in which lower values indicate a better fit. We also used entropy, a measure that summarizes the uncertainty of the posterior classification and provides an indication of how the classes defined by the model can discriminate (the closer to one, the better the model) ${ }^{28}$. In addition, we chose the model based on the interpretability of the latent classes. We compared models that had latent classes ranging from 2 to 6 , using the AIC, BIC, and entropy criteria. For each participating city, individuals were weighted using the Gile ${ }^{29}$ estimator, through the RDS Analyst program ${ }^{30}$. Then, we estimated the proportions of DSO as their respective $95 \%$ confidence intervals (CI). We proceeded to organize the data from the 12 cities in a single database, in which each city was considered a stratum, and data were analyzed using the complex samples routine with Stata 15.1 (Stata Corp., CollegeStation, TX, USA). Finally, we described the distribution of the DSO classes among the MSM who suffered discrimination.

\section{RESULTS}

Most (56\%) of the MSM ( $\mathrm{n}=4,176)$ was young ( $<25$ years old); $86.3 \%$ of them were single, and $53.1 \%$ had a religion; $70.3 \%$ had a high school or college degree; $70.6 \%$ reported that their skin color was black or brown; and almost half of the participants were classified as belonging to the higher A-B (44.2\%) and middle C (46.7\%) socioeconomic strata, whilst a minority was classified as lower D-E (19\%). Most of them reported that they had already been discriminated against because of their sexual orientation (65\%), more than a third reported having felt afraid of walking in public places in the last 12 months (39.5\%), and about one fifth of the participants reported having already suffered physical $(23.5 \%)$ or sexual assault $(21 \%)$. (Table 1$)$.

Of the total of 4,176 respondents, 4,092 (98\%) were included in LCA analysis for the construction of the variable DSO. We excluded $2 \%$ of respondents due to the lack of data on discrimination. We evaluated models ranging from 2 to 6 classes and chose the model with 4 classes because it showed intermediate statistical parameters, as better parsimony and interpretability. We named the classes of DSO as "very high", "high", "moderate" and "low", having been designated through analysis of the distribution of their probabilities. Although the 4 classes model did not present the best entropy $(82 \%)$ and AIC $(39,168.6)$ values, it showed the best BIC $(39,516.1)$ and adjusted BIC values $(39,584.9)$ (Table 2$)$.

We discriminated all variables in the 4 latent classes, classified as "very high", "high", "moderate" and "low" DSO, with estimates of 2.2\%, 16.4\%, $35.1 \%$, and 46.19\%, respectively (Figure 1). Regarding the four dimensions, the distribution of these variables indicates that within the "discrimination in the work sphere", $11 \%$ of the MSM were not selected for a job or were fired because of DSO; in the dimension "discrimination in the educational setting", 
Table 1. Characteristics of the MSM population in the 12 Brazilian cities, 2016.

\begin{tabular}{|c|c|c|c|c|}
\hline \multirow{2}{*}{ Variables } & \multirow{2}{*}{$\mathrm{n} / \mathrm{N}^{1}$} & \multirow{2}{*}{$\%^{1}$} & \multicolumn{2}{|c|}{$95 \% \mathrm{Cl}$} \\
\hline & & & LL & UL \\
\hline \multicolumn{5}{|l|}{ Age } \\
\hline$<25$ years old & $2,503 / 4,129$ & 56.1 & 52.4 & 59.7 \\
\hline$\geq 25$ years old & $1,626 / 4,129$ & 43.9 & 40.3 & 47.6 \\
\hline \multicolumn{5}{|l|}{ Color/Race } \\
\hline White & $1,285 / 4,106$ & 31.5 & 28.2 & 35 \\
\hline Black & $903 / 4,106$ & 22.7 & 19.7 & 26.1 \\
\hline Brown & $1,768 / 4,106$ & 41.8 & 38.3 & 45.3 \\
\hline Indigenous & $64 / 4,106$ & 1.9 & 1 & 3.3 \\
\hline Yellow & $86 / 4,106$ & 2.2 & 1.5 & 3.3 \\
\hline \multicolumn{5}{|l|}{ Schooling } \\
\hline College / High school degree & $3,115 / 4,132$ & 70.3 & 67.1 & 73.3 \\
\hline $\begin{array}{l}\text { Incomplete High School / Complete } \\
\text { elementary or middle school }\end{array}$ & $1,017 / 4,132$ & 29.7 & 26.8 & 32.9 \\
\hline \multicolumn{5}{|l|}{ Religion } \\
\hline Yes & $2,176 / 4,096$ & 53.1 & 49.5 & 56.7 \\
\hline No & $1,920 / 4,096$ & 46.9 & 43.3 & 50.6 \\
\hline \multicolumn{5}{|l|}{ Marital status } \\
\hline Single/Separated/Widower & $3,578 / 4,115$ & 86.3 & 83.6 & 88.6 \\
\hline Married/living with a partner & $537 / 4,115$ & 13.7 & 11.4 & 16.4 \\
\hline \multicolumn{5}{|l|}{ Socioeconomic strata } \\
\hline A-B (higher) & $1,889 / 4,127$ & 42.4 & 38.9 & 46 \\
\hline $\mathrm{C}$ (middle) & $1,664 / 4,127$ & 41.7 & 38.1 & 45.3 \\
\hline D-E (lower) & $574 / 4,127$ & 15.9 & 13.5 & 18.6 \\
\hline \multicolumn{5}{|l|}{ Experience of physical violence } \\
\hline No & $3,150 / 4,078$ & 76.5 & 73.1 & 79.6 \\
\hline Yes & $928 / 4,078$ & 23.5 & 20.4 & 26.9 \\
\hline \multicolumn{5}{|l|}{ Experience of sexual violence } \\
\hline No & $3,207 / 4,085$ & 79.1 & 75.7 & 82.1 \\
\hline Yes & $878 / 4,085$ & 21 & 18 & 24.3 \\
\hline \multicolumn{5}{|l|}{ Self-reported discrimination } \\
\hline No & $1,234 / 4,097$ & 35 & 31.7 & 38.4 \\
\hline Yes & $2,863 / 4,097$ & 65 & 61.6 & 68.3 \\
\hline
\end{tabular}

'Estimate weighted using Gile's SS; Cl: confidence interval; LL: lower limit; UL: upper limit. 
Table 2. Diagnostic tests of the latent class analysis, classes 2-6.

\begin{tabular}{|l|c|c|c|c|c|}
\hline \multicolumn{1}{|c|}{ Diagnostic tests } & 2 classes & 3 classes & 4 classes & 5 classes & 6 classes \\
\hline Akaike (AIC) & $40,907.8$ & $39,456.2$ & $39,168.6$ & $39,040.1$ & $38,934.4$ \\
\hline Bayesian (BIC) & $41,078.3$ & $39,715.2$ & $39,516.1$ & 39,476 & $39,458.7$ \\
\hline BIC-sample-size adjusted & $40,992.5$ & $39,584.9$ & $39,341.3$ & $39,256.7$ & 39,194 \\
\hline Entropy & $86 \%$ & $84 \%$ & $82 \%$ & $79 \%$ & $81 \%$ \\
\hline
\end{tabular}

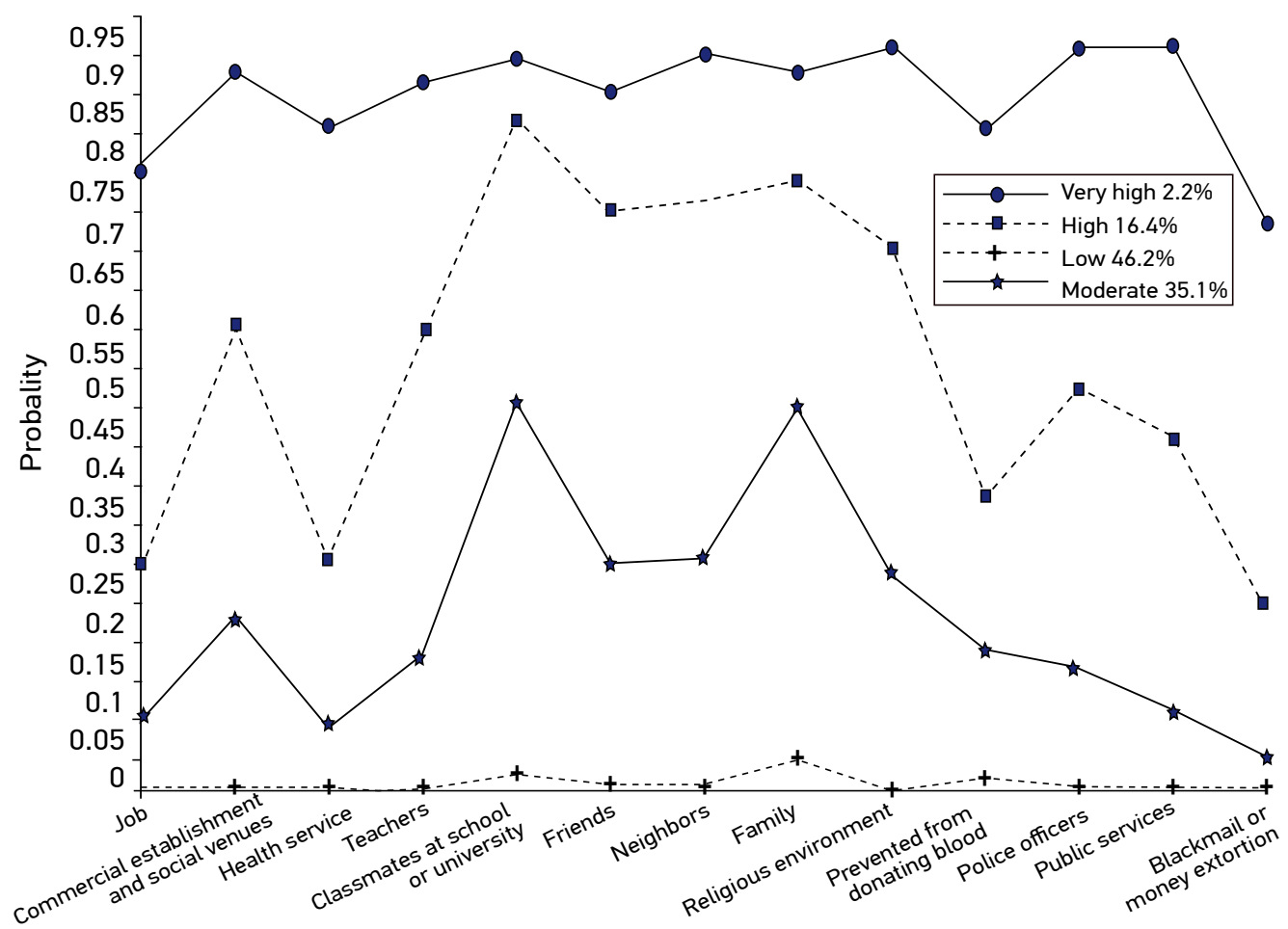

Figure 1. DSO model with 4 latent classes, according to the probability of inclusion in the classes based on the affirmative answer to the item.

$14.9 \%$ of them were mistreated or marginalized by teachers at school or university, and $27.1 \%$ of them were mistreated or marginalized by classmates in school or university; in the dimension "discrimination in the private domain", $23.5 \%$ were excluded from groups of friends or marginalized by them, $25.7 \%$ were excluded from groups of neighbors or marginalized by them, and $30.7 \%$ were excluded or marginalized in their family environment; in the dimension "discrimination in the public sphere", $18.6 \%$ were excluded or marginalized in a religious environment, $16.2 \%$ were poorly served or prevented from entering commercial establishments or social venues, $10.9 \%$ were prevented from donating blood, $15.3 \%$ were mistreated by police or poorly served in police stations, $7.3 \%$ were blackmailed or extorted, $9 \%$ were poorly served by health services or by health professionals, and $13 \%$ were poorly served or ill-treated in public services (Table 3 ). 
Table 3. DSO model with 4 latent classes according to the probability of inclusion in the classes based on the affirmative answer to the item.

\begin{tabular}{|c|c|c|c|c|c|c|c|c|}
\hline & & & & & VHDSO & HDSO & MDSO & LDSO \\
\hline Variables & $\mathrm{n} / \mathrm{N}^{1}$ & $\%^{2}$ & $\mathrm{LL}^{2}$ & $U L^{2}$ & $\begin{array}{l}(n=92 ; \\
2.2 \%)\end{array}$ & $\begin{array}{c}(n=673 ; \\
\left.16.4 \%{ }^{\prime}\right)\end{array}$ & $\begin{array}{c}(n=1,437 ; \\
35.1 \%)\end{array}$ & $\begin{array}{c}(n=1,890 ; \\
\left.46.19 \%{ }^{\prime}\right)\end{array}$ \\
\hline Job & $427 / 4,071$ & 11 & 8.7 & 13.7 & $83.8 \%$ & $28.6 \%$ & $10.5 \%$ & $0.7 \%$ \\
\hline Teachers & $746 / 4,083$ & 14.9 & 12.7 & 17.4 & $95 \%$ & $58.6 \%$ & $18.5 \%$ & $0.1 \%$ \\
\hline Classmates & $1,432 / 4,081$ & 27.1 & 24.3 & 30.1 & $98.2 \%$ & $85.4 \%$ & $50.3 \%$ & $2.8 \%$ \\
\hline Friends & $1,030 / 4,081$ & 23.5 & 20.5 & 26.9 & $93.6 \%$ & $74.1 \%$ & $30.1 \%$ & $1 \%$ \\
\hline Neighbors & $1,048 / 4,076$ & 25.7 & 22.5 & 29.1 & $98.9 \%$ & $75.8 \%$ & $30.6 \%$ & $0.9 \%$ \\
\hline Family & $1,404 / 4,078$ & 30.7 & 27.5 & 34 & $96 \%$ & $77.3 \%$ & $49 \%$ & $5.3 \%$ \\
\hline $\begin{array}{l}\text { Religious } \\
\text { environment }\end{array}$ & $947 / 4,058$ & 18.6 & 16.2 & 21.4 & $100 \%$ & $69.2 \%$ & $28.1 \%$ & $0.2 \%$ \\
\hline $\begin{array}{l}\text { Commercial } \\
\text { establishments }\end{array}$ & $819 / 4,082$ & 16.2 & 13.9 & 18.8 & $96.1 \%$ & $58.8 \%$ & $23.1 \%$ & $0.4 \%$ \\
\hline $\begin{array}{l}\text { Prevented from } \\
\text { donating blood }\end{array}$ & $621 / 4,030$ & 10.9 & 9.3 & 12.8 & $88 \%$ & $37.3 \%$ & 18.9 & $2.1 \%$ \\
\hline Police officers & $687 / 4,072$ & 15.3 & 12.9 & 18 & $100 \%$ & $51.6 \%$ & 16.8 & $0.7 \%$ \\
\hline $\begin{array}{l}\text { Blackmail or } \\
\text { money extortion }\end{array}$ & $558 / 4,069$ & 7.3 & 5.7 & 9.2 & $74.6 \%$ & $23.4 \%$ & $5.6 \%$ & $0.4 \%$ \\
\hline Health services & $422 / 4,085$ & 9 & 7.4 & 10.9 & $88.2 \%$ & $30.2 \%$ & $9.2 \%$ & $0.4 \%$ \\
\hline Public services & $310 / 4,070$ & 13 & 11 & 15.3 & $100 \%$ & $51.6 \%$ & $11,2 \%$ & $0.5 \%$ \\
\hline
\end{tabular}

Those MSM who were classified with “very high DSO” $(\mathrm{n}=92)$ scored $80 \%$ or higher in all variables comprising the latent classes, except for the variable "blackmailed or extorted money" (74.6\%). MSM who were classified with "high DSO" ( $\mathrm{n}=673$ ) were those whose affirmative answers regarding discrimination ranged from $30 \%$ to $77 \%$, except for some variables. We classified MSM with "moderate DSO" $(\mathrm{n}=1,437)$ when their answers regarding discrimination ranged roughly from $6 \%$ to $30 \%$, except for some variables. MSM classified as having "low DSO" ( $\mathrm{n}=1,890)$ were those whose affirmative answers to variables in all domains were lower than or equal to $5.3 \%$ (Table 3 ).

\section{DISCUSSION}

We found a high proportion of DSO in this population, having been reported by about two-thirds of the study participants. This was significantly higher than the proportion found 
in a previous survey conducted in 2009 with this population in 10 Brazilian cities $(27.7 \%$, 95\% CI: 26.2-9.91). Part of this increase could be explained by government decisions that have excluded the LGBT population from preventive programs for HIV infection and other STIs, such as syphilis.

According to our study, the probability of suffering DSO, using ACL, varied greatly between the four levels of discrimination, classified as very high (2.2\%), high $(16.4 \%)$, moderate $(35.1 \%)$, and low (46.2\%). Possibly, the MSM "coming out of the closet" process (voluntary disclosing one's own sexual orientation) may influence these different levels, for they are the result of different levels of publicly sharing one's sexual orientation and (homo)sexuality. The lives of those who have desires and affections for people of the same gender are marked by the dilemma regarding the disclosure of their sexual orientation, and one of the reasons for deciding with whom, how, and when this information will be shared is precisely the exposure to $\mathrm{DSO}^{31-33}$.

DSO can affect various relationships of MSM in society. Most of the reports indicated the DSO occurred in the family environment (30.7\%). Studies in other countries report much lower estimates: $10.2 \%$ among MSM in Lomé, Togo ${ }^{34}, 8.7 \%$ in 3 African countries (Ivory Coast, Togo, and Burkina Faso) ${ }^{35}$, and $23.8 \%$ in 8 African countries (Burkina Faso, Ivory Coast, Gambia, Lesotho, Malawi, Senegal, Swaziland, and Togo $)^{36}$. In Kampala, Uganda, $39 \%$ of the MSM that participated in the study reported having suffered homophobic abuse (including exclusion, isolation, and verbal and physical violence), and $25.4 \%$ of such abuses were carried out by family members ${ }^{37}$.

In Brazil, surveys conducted in LGBT Pride Parades in several capital cities indicated that the family context is a key factor in the process of disclosing one's sexual orientation ${ }^{38-40}$. Non-heterosexual youths' need to come out of the closet would involve loyalty to and respect for family relations ${ }^{41}$. Once DSO is directly related to the knowledge or suspicion of non-heterosexuality, the number of reports of DSO may likely be greater in the family environment because in this context one's sexuality is more exposed. In a study conducted in the city of São Paulo, $80 \%$ of the MSM investigated reported that they had disclosed their sexual orientation to their families; when different levels of disclosure were verified, researchers observed a tendency of increased DSO in the familiar environment as the exposure of their sexuality was greater ${ }^{42}$.

It is precisely in the context of interpersonal relationships that we have found the highest frequencies of DSO: $27.1 \%, 23.5 \%$, and $25.7 \%$ of the MSM reported that they had been excluded or marginalized because of their sexual orientation in groups of school or college classmates, of friends and of neighbors, respectively. A previously cited study estimated that $21.7 \%$ of the MSM in the survey had been rejected by their friends because of their sexual orientation ${ }^{36}$, and another study reported that friends and acquaintances are responsible for $24.1 \%$ of the discrimination against $\mathrm{MSM}^{37}$.

Noteworthy that many reported having been mistreated or poorly served due to their sexual orientation in services or by professionals whose work should be guided by a human rights' perspective - such as workers in general public services, police stations, health services, 
and teachers in schools and colleges. A study conducted in three African countries showed $2.3 \%$ of the MSM interviewed reported mistreatment in health services because of their sexual orientation, and $6.9 \%$ said they had been the target of "gossip" by health profession$\mathrm{als}^{35}$. In Nepal, $14.1 \%$ of the MSM who were interviewed reported DSO from police officers and other security forces, $16 \%$ of them reported having been discriminated against in public spaces, and $2.3 \%$ in health services ${ }^{21}$.

In 2011, the The Brazilian Supreme Court (STF) has assured that, in Brazil, same-sex couples have the same rights as those of couples formed by persons of opposite genres ${ }^{43}$. The legal recognition of homosexual relationships, such as the marriage between people of the same gender, is an important achievement for the Brazilian LGBT movement that has granted legitimacy and given greater visibility to non-heterosexual relationships. The Ministry of Health established, also in 2011, the National Health Policy for Lesbians, Gays, Bisexuals, Transvestites, and Transsexuals, whose goals are to promote full health for these populations, to eliminate discrimination, and to reduce social inequalities. Despite having established such a national policy, in effect few actions have been implemented based on it $^{44}$ and, in fact, self-reported discrimination increased significantly among MSM, as our study has demonstrated. Policy and programs have in fact been a result of the LGBT political movement and advocacy, demanding that the Brazilian State develop public policies; however, these same achievements may very well have triggered reactions from more conservative segments of society ${ }^{45}$. The high levels of DSO found in our study might reflect such a clash between different social groups.

Structural stigma refers to discrimination through institutional policies, laws, and practices $^{3}$. It is a social phenomenon embedded in cultural norms and in institutional policies that in turn restrict the opportunities, the resources, and the well-being of stigmatized people ${ }^{46}$. In Brazil, such structural stigma is observed in the legal prohibition of blood donation by men who have had sex with men in the last 12 months, regulated by Ordinance No. 158, of February $4,2016^{47}$. Once there is the availability of fourth generation laboratory tests that reduce the window period to about 18 days (interquartile range from 16 to 24 days) ${ }^{48}$, such regulation is discriminatory. In addition, the scientific community has discussed changes in blood safety surveillance by the clinical identification of sexual practices, and not by labeling population groups ${ }^{49}$.

DSO can also affect opportunities or permanence in the labor market. In our study, $16.6 \%$ of the MSM who reported discrimination were not admitted into jobs or were fired due to DSO. This number is much higher than those estimated in other studies in eight African countries $(2.9 \%)^{36}$ and in Nepal $(4.8 \%)^{21}$. This last study also showed $7.8 \%$ of the MSM interviewed reported having perceived discrimination at work ${ }^{21}$.

Our study presents a limitation due to our instruments for data collection. Our instruments were not planned for DSO evaluation: the goal was rather a monitoring study of HIV prevalence and associated factors. Thus, important information regarding discrimination, such as the time or period of exposure to DSO, the context in which the episode of discrimination occurred, the intensity and frequency of discrimination, were not 
collected. RDS furthermore presents limitations regarding sample representativeness, potential selection biases for sampling social networks, and the possibility of dependency among the individuals selected ${ }^{29,50,51}$. Specific analysis for data collected using this method seeks to reduce these biases.

\section{CONCLUSION}

This study reports a high proportion of DSO among MSM in Brazil, and these results should be used for surveillance and aiming for respect towards human rights. In addition, it shows an alternative form of analyzing DSO. Using LCA, MSM were classified into 4 classes, and high discrimination was observed among the latent classes through the variables chosen for the model. This analysis can capture important nuances of DSO, which may help in understanding the phenomenon, and of factors possibly associated with situations of high and very high discrimination that otherwise would not be perceived.

\section{REFERENCES}

1. Herek GM, Chopp R, Strohl D. Sexual stigma: putting sexual minority health issues in context. In: Meyer IH, Northridge ME, editors. The health of sexual minorities. Boston: Springer; 2007. p. 171-208.

2. Whitley BE, Kite ME. The psychology of prejudice and discrimination; vol. 53. Belmont: Wadsworth; 2010. p. 1689-99.

3. Pescosolido BA, Martin JK. The stigma complex. Annu Rev Sociol. 2015;41(1):87-116. https:// doi. org/10.1146/annurev-soc-071312-145702

4. Krieger N. Embodying inequality: a review of concepts, measures, and methods for studying health consequences of discrimination. Int $\mathrm{J}$ Heal Serv. 1999;29(2):295-352. https: / / doi.org/10.2190/ M11W-VWXE-KQM9-G97Q

5. Parker R, Aggleton P. HIV and AIDS-related stigma and discrimination: a conceptual framework and implications for action. Soc Sci Med. 2003;57(1):1324. https: / / doi.org/10.1016/S0277-9536(02)00304-0

6. Meyer IH. Prejudice, social stress, and mental health in lesbian, gay, and bisexual populations: conceptual issues and research evidence. Psychol Bull. 2003;129(5):674-97. h ttps:// doi.org/10.1037/0033-2909.129.5.674

7. Sue DW. Microaggressions in everyday life: race, gender, and sexual orientation. Hoboken: John Wiley \& Sons; 2010.
8. Brubaker MD, Garrett MT, Dew BJ. Examining the relationship between internalized heterosexism and substance abuse among lesbian, gay and bisexual individuals: a critical review. J LGBT Issues Couns. 2009;3(1):62-89. https:// doi. org/10.1080/15538600902754494

9. Lelutiu-Weinberge C, Pachankis JE, Golub SA, Walker JJ, Bamonte AJ, Parsons JT. Age cohort differences in the effects of gay-related stigma, anxiety and identification with the gay community on sexual risk and substance use. AIDS Behav. 2013;17(1):340-9. https://doi. org/10.1007/s10461-011-0070-4

10. Weber GN. Using to numb the pain: substance use and abuse among lesbian, gay, and bisexual individuals. J Ment Heal Couns. 2008;30(1):31-48. http:/ / dx.doi. org/10.17744/mehc.30.1.2585916185422570

11. Díaz RM, Ayala G, Bein E, Henne J, Marin BV. The impact of homophobia, poverty, and racism on the mental health of gay and bisexual Latino men: findings from 3 US cities. Am J Public Health. 2001;91(6):927-32. http:/ / dx.doi.org/10.2105/ AJPH.91.6.927

12. Lewis RJ, Derlega VJ, Griffin JL, Krowinski AC. Stressors for gay men and lesbians: life stress, gayrelated stress, stigma consciousness, and depressive symptoms. J Soc Clin Psychol. 2003;22(6):716-29. https: / / doi.org/10.1521/jscp.22.6.716.22932 
13. Hylton E, Wirtz AL, Zelaya CE, Latkin C, Peryshkina A, Mogilnyi V, et al. Sexual identity, stigma, and depression: the role of the "Anti-gay Propaganda Law" in mental health among men who have sex with men in Moscow, Russia. J Urban Heal. 2017;94(3):319-29. https: / / doi.org/10.1007/s11524-017-0133-6

14. Hatzenbuehler ML, Nolen-Hoeksema S, Erickson SJ. Minority stress predictors of HIV risk behavior, substance use, and depressive symptoms: results from a prospective study of bereaved gay men. Health Psychol. 2008;27(4):455-62. http://dx.doi. org/10.1037/0278-6133.27.4.455

15. Puckett JA, Newcomb ME, Ryan DT, Swann G, Garofalo R, Mustanski B. Internalized homophobia and perceived stigma: a validation study of stigma measures in a sample of young men who have sex with men. Sex Res Social Policy. 2017;14(1):1-16. http: / / dx.doi.org/10.1007/s13178-016-0258-5

16. Altman D, Aggleton P, Williams M, Kong T, Reddy V, Harrad D, et al. Men who have sex with men: stigma and discrimination. Lancet. 2012;380(9839):439-45. https: / / doi.org/10.1016/S0140-6736(12)60920-9.

17. Krieger N. Discrimination and health inequities. Int J Heal Serv. 2014;44(4):643-710. https: / / doi. org/10.2190/HS.44.4.b

18. Bogart LM, Landrine H, Galvan FH, Wagner GJ, Klein DJ. Perceived discrimination and physical health among HIV-positive black and Latino men who have sex with men. AIDS Behav. 2013;17(4):143141. https: / / doi.org/10.1007/s10461-012-0397-5

19. Bogart LM, Wagner GJ, Galvan FH, Klein DJ. Longitudinal relationships between antiretroviral treatment adherence and discrimination due to HIV-serostatus, race, and sexual orientation among African-American men with HIV. Ann Behav Med. 2010;40(2):184-90. https:// doi.org/10.1007/ s12160-010-9200-x

20. Tohme J, Egan JE, Friedman MR, Stall R. Psychosocial correlates of condom use and HIV testing among MSM refugees in Beirut, Lebanon. AIDS Behav. 2016;20(3):417-25. https:/ / doi.org/10.1007/ s10461-016-1498-3

21. Kohlbrenner V, Deuba K, Karki DK, Marrone G. Perceived discrimination is an independent risk factor for suicidal ideation among sexual and gender minorities in Nepal. PLoS One. 2016;11(7):1-15. https: / / doi.org/10.1371/journal.pone.0159359

22. Collins LM, Lanza ST. Latent class and latent transition analysis: with applications in the social, behavioral, and health sciences. Hoboken: Wiley; 2010.
23. Guimaraes MDC, Kendall C, Magno L, Rocha GMH, Knauth DR, Leal AF, et al. Comparing HIV riskrelated behaviors between 2 RDS national samples of MSM in Brazil, 2009 and 2016. Medicine (Baltimore). 2018;97(1 Suppl 1):S62-8. https:/ / doi.org/10.1097/ MD.0000000000009079

24. Kerr L, Kendall C, Guimarães MDC, Salani Mota R, Veras MA, Dourado I, et al. HIV prevalence among men who have sex with men in Brazil. Medicine (Baltimore). 2018;97:S9-15. https:/ / doi.org/10.1097/ MD.0000000000010573

25. Barbosa Júnior A, Pascom ARP, Szwarcwald CL, Kendall C, McFarland W. Transfer of sampling methods for studies on most-at-risk populations (MARPs) in Brazil. Cad Saúde Pública. 2011;27(Suppl 1):S36-44. http:/ / dx.doi.org/10.1590/ S0102-311X2011001300005

26. Heckathorn D. Respondent-driven sampling: a new approach to the study of hidden populations. Social Problems. 1997;44(2):174-99. https://doi. org/10.2307/3096941

27. Muthén LK, Muthén BO. Mplus user's guide. 6th ed. Los Angeles: Muthén \& Muthén; 2012.

28. Celeux G, Soromenho G. An entropy criterion for assessing the numbers of clusters in a mixture model. J Classif. 1996;13(2):195-212. https: / / doi. org/10.1007/BF01246098

29. Gile KJ, Handcock MS. Respondent-Driven Sampling: an assessment of current methodology. Sociol Methodol. 2010;40(1):285-327. https:/ / doi. org/10.1111/j.1467-9531.2010.01223.x

30. Handcock MS, Fellows IE, Gile KJ. RDS Analyst: Software for the Analysis of Respondent-Driven Sampling Data, Version 0.42 [Internet]. 2014 [cited 2019 Jan 9]. Available from: http:/ /hpmrg.org

31. Harry J. Being out: a general model. J Homosex. 1993;26(1):25-39. https:// doi.org/10.1300/ J082v26n01_03

32. Pecheny M. Identidades discretas. In: Arfuch L, editor. Identidades, sujetos y subjetividades: narrativas de la diferencia [Internet]. Buenos Aires: Prometeo; 2002 [cited 2019 Jan 9]. p. 125-147. Avaiable from: http://www.ram-wan.net/restrepo/identidad/ identidades discretas.pdf

33. Orne J. "You will always have to 'out' yourself": reconsidering coming out through strategic outness. Sexualities. 2011;14(6):681-703. https: / doi. org / 10.1177/1363460711420462

34. Ruiseñor-Escudero H, Grosso A, Ketende S, Pitche V, Simplice A, Tchalla J, et al. Using a social ecological framework to characterize the correlates of HIV 
among men who have sex with men in Lomé, Togo. AIDS Care. 2017;29(9):1169-77. https:// doi.org/ 10.1080/09540121.2017.1280122

35. Stahlman S, Liestman B, Ketende S, Kouanda S, Ky-Zerbo O, Lougue M, et al. Characterizing the HIV risks and potential pathways to HIV infection among transgender women in Cote d'Ivoire, Togo and Burkina Faso. J Int AIDS Soc. 2016;19(Suppl 2):1-12. https:// doi.org/ 10.7448/IAS.19.3.20774

36. Poteat T, Ackerman B, Diouf D, Ceesay N, Mothopeng T, Odette K, et al. HIV prevalence and behavioral and psychosocial factors among transgender women and cisgender men who have sex with men in 8 African countries: a cross-sectional analysis. PLoS Med. 2017;14(11):e1002422. https:// doi.org/10.1371/ journal.pmed.1002422

37. Hladik W, Barker J, Ssenkusu JM, Opio A, Tappero JW, Hakim A, et al. HIV infection among men who have sex with men in kampala, uganda-a respondent driven sampling survey. PLoS One. 2012;7(5):e38143. https: / / doi.org/10.1371/journal.pone.0038143

38. Carrara S, Ramos S, Caetano M. Política, direitos, violência e homossexualidade: Pesquisa $8^{a}$ Parada do Orgulho GLBT - Rio 2003 [Internet]. Rio de Janeiro: Pallas; 2003 [cited 2019 Jan 9]. Available from: http: / / www.clam.org.br/uploads/ conteudo/ relatorioglbt.pdf

39. Carrara S, Ramos S, Simões JA, Facchini R. Política, direitos, violência e homossexualidade. Pesquisa 9a Parada do Orgulho GLBT - São Paulo 2005 [Internet]. Rio de Janeiro: Cepesc; 2006 [cited 2019 Jan 9]. Available from: http://www.clam.org.br/ uploads/arquivo/paradasp_2005.PDF

40. Ramos S, Carrara S. Política, direitos, violência e homossexualidade. Pesquisa $9^{a}$ Parada do Orgulho GLBT - Rio 2004 [Internet]. Rio de Janeiro: Cepesc; 2004 [cited 2019 Jan 9]. Available from: http: / / www. clam.org.br/uploads/conteudo/paradario2004.pdf

41. Cleve R. Disclosure decisions of sexual identity in young adult males: emergent cross-cultural themes utilizing grounded theory. Chicago: Chicago School of Professional Psychology; 2012.

42. De Deus LFA. Contextos de revelação da orientação sexual: no final do arco-íris tem um pote de ouro? [dissertation]. São Paulo: Faculdade de Saúde Pública da USP; 2014.

43. Costa ABC, Nardi HC. O casamento "homoafetivo" e a política da sexualidade: implicações do afeto como justificativa das uniões de pessoas do mesmo sexo. Rev Estud Fem. 2015;23(1):137-50. http://dx.doi. org/10.1590/0104-026X2015v23n1p/137
44. Popadiuk GS, Oliveira DC, Signorelli MC. The National Policy for Comprehensive Health of Lesbians, Gays, Bisexuals and Transgender (LGBT) and access to the Sex Reassignment Process in the Brazilian Unified Health System (SUS): progress and challenges. Cien Saude Colet. 2017;22(5):1509-20. http:// dx.doi. org/10.1590/1413-81232017225.32782016

45. Facchini R, Sívori H. Conservadorismo, direitos, moralidades e violência: situando um conjunto de reflexões a partir da Antropologia. Cad Pagu. 2017;(50):e175000. http:// dx.doi.org/10.1590/180 94449201700500000

46. Hatzenbuehler ML, Phelan JC, Link BG. Stigma as a fundamental cause of population health inequalities. Am J Public Health. 2013;103(5):813-21. http:// dx.doi. org/10.2105/ AJPH.2012.301069

47. Ministério da Saúde (BR). Portaria n ${ }^{\circ} 158$, de 4 de fevereiro de 2016. Diário Oficial da União [Internet]. Brasília, DF; 2016 fev. [cited 2018 Jan 9];1:37. Available from: http: / bvsms.saude.gov.br/bvs/saudelegis / gm/2016/prt0158_04_02_2016.html

48. Taylor D, Durigon M, Davis H, Archibald C, Konrad B, Coombs D, et al. Probability of a falsenegative HIV antibody test result during the window period: a tool for pre- and post-test counselling. Int J STD AIDS. 2015;26(4):215-24. http:/ / dx.doi. org/10.1177/0956462414542987

49. Haire B, Whitford K, Kaldor JM. Blood donor deferral for men who have sex with men: still room to move. Transfusion. 2018;58(3):816-22. http: / / dx.doi. org/10.1111/trf.14445

50. Gile KJ, Johnston LG, Salganik MJ. Diagnostics for respondent-driven sampling. J R Stat Soc Ser A Stat Soc. 2015;178(1):241-69. http:/ / dx.doi.org/10.1111/rssa.12059

51. SalganikMJ. Commentary: respondent-driven sampling in the real world. Epidemiology. 2012;23(1):148-50. http:/ / dx.doi.org/10.1097/EDE.0b013e31823b6979

Received on: 02/12/2019

Approved on: 03/12/2019

Acknowledgements: To the Ministry of Health and to the Department of Surveillance, Prevention and Control of STI, HIV / AIDS, and Viral Hepatitis (DIAHV) for funding. To gays and other MSM who were interviewed. To the Brazilian HIV / MSM Surveillance Group: Alexandre Kerr Pontes (Federal University of Rio de Janeiro), Ana Cláudia Camillo (Alfredo da Mata Foundation), Ximena Pamela Diaz (University of Brasília), Raimunda Hermelinda M. Macena (Federal University of Ceará), Maria do Socorro 
Cavalcante (Department of Health of Ceará), Cristina Pimenta and Ana Roberta Pati Pascom (DIAHV).

Authors' contribution: Magno L conceived the study, analyzed the data, wrote and edited the manuscript. Guimarães MDC and Mota RMS collaborated to data analysis, as well as to the writing and editing of the text. Dourado IC, De Deus LFA, Leal AF and Knauth DR also wrote and edited the manuscript. Silva LAV, Veras MA, Brito AM, Rocha GM, Lima LNGC, Kendall C, Motta-Castro ARC, Merchan-Hamann E, Kerr LRFS and Dourado IC reviewed the final text. 